\title{
Seedling emergence of five varieties of citric rootstocks grown in environments with different levels of shading
}

\author{
Madlles Queiroz Martins ${ }^{1} \otimes$, Ruimário Inácio Coelho², Tiago de Souza Marçal ${ }^{3}$, Izaias dos Santos \\ Bregonci $^{4}$ and Filipe de Jesus Colwell ${ }^{5}$
}

\begin{abstract}
The emergence of citrus seedlings is influenced by several factors. One is the degree of brightness. The objective of the experiment was to evaluate the influence of four environments in the emergence of seedlings of five citrus varieties rootstocks. The work was carried out on private property located in the city of Alegre-ES, located at $20^{\circ} 49^{\prime}$ south latitude and $41^{\circ} 32^{\prime}$ west longitude and $322 \mathrm{~m}$ altitude. The experimental design was completely randomized in a split plot, with four rooms consisting of $0,30,50$ and $80 \%$ shading in the plot and five varieties of rootstocks subplots, with four repetitions and twenty-five seeds per replicate. The rootstocks used were the Rangpur lime, lemon Volkameriano, Poncirus trifoliata, 'Swingle' citrumelo and
\end{abstract}

Received: 25 April 2014 / Accepted revised version: 26 June 2014 / Published online: 22 July 2014

(C) Horizon e-Publishing Group

CITATION

Martins, M. Q., Coelho, R. I., Marçal, T. S., Bregonci, I. S., \& Colwel, F. J. (2014). Seedling emergence of five varieties of citric rootstocks grown in environments with different levels of shading. Plant Science Today, 1(3), 131-139. http://dx.doi.org/10.14719/pst.2014.1.3.37

AUTHOR AFFILIATIONS

${ }^{1}$ Engenheiro Agrônomo, mestre em Produção Vegetal e doutorando em Genética e Melhoramento - Centro de Ciências Agrárias da Universidade Federal do Espírito Santo/CCA-UFES - Alto Universitário, s/nº, Guararema - CP. 16 - CEP: 29500-000 - Alegre-ES - Brasil.

2 Professor - Departamento de Produção Vegetal - Centro de Ciências Agrárias da Universidade Federal do Espírito Santo/CCA-UFES - Alto Universitário, s/nº Guararema - CP. 16 - CEP: 29500-000 - Alegre-ES Brasil.

3 Graduando em Agronomia, Bolsista de Iniciação Científica do CNPq Centro de Ciências Agrárias da Universidade Federal do Espírito Santo/CCA-UFES - Alto Universitário, s/n², Guararema - CP. 16 - CEP: 29500-000 - Alegre-ES - Brasil.

4 Engenheiro Agrônomo, mestre em Produção Vegetal, extensionista do INCAPER, Alegre-ES - Brasil. Alto Universitário, s/n, CP 16, CEP: 29500-000.

5 Biólogo, Mestre em Biologia da Conservação, Bolseiro de Investigação Grupo Interações Planta-Ambiente (Plant Stress), Centro de Ambiente, Agricultura e Desenvolvimento (BioTrop), Instituto de Investigação Científica Tropical, I.P. (IICT) - Quinta do Marquês - Av. República 2784-505 - Oeiras, Portugal.
Flying Dragon. After 60 days of sowing, emergence rate index, emergence percentage, leaf number and height were evaluated. At 124 days, leaf area, total chlorophyll $(a+b)$, root dry mass and shoot were evaluated. The citric rootstocks tested responded differently when subjected to shading, and can use physiological and morphological mechanisms to maintain or even improve the emergence and seedling vigor. It was observed that the $P$. trifoliata rootstock obtained better performance when compared to others and that $50 \%$ shading can be adopted in this stage of citrus seedling production since it reduces seedling time in the tubes and does not affect the seedling quality.

Keywords: grafting; seeds; shade cloth; tubes.

\section{Introduction}

The citric seedling is formed, almost entirely, using the technique of grafting budding. Propagation by seed hasn't been used for several decades, except for obtaining rootstocks (Siqueira et al., 2002). The Rangpur lime (Citrus limonia Osbeck), until the early 70's, corresponded to 99\% of rootstocks planted in the state of São Paulo. Their share was reduced to $72 \%$ in the late 80 's. In turn, the Cleopatra mandarin (Citrus reshni Hort. Ex Tan.) had its share of $0.3 \%$, in 1970, increase to 24\% between 1984 and 1988 (Silva et al., 1990). According to Fundecitrus (1996) the Rangpur lime, the Cleopatra and 'Swingle' citrumelo [Citrus paradisi Mac f. x Poncirus trifoliata (L.) Raf.] respectively accounts for $85 \%, 9 \%$ and $3 \%$ of the rootstocks used in the same state de São Paulo, Brazil. The tendency to diversify the use of rootstocks is increasing, with promising results. According to Pompeu Junior et al. (1986), employing a single rootstock for all varieties of canopy probably won't allow to meet the inherent characteristics of each cultivar, preventing the plant from showing all its productive potential, and constitute itself a problem in case of endemic diseases. In this sense, there is a need for further studies with greater number of citric rootstock varieties.

According to Fundecitrus (2009), the evolution of inspection history in citric seedlings in Sao Paulo reveals, that from 2005 to 2009, the number of farms decreased 
from 550 to 517 greenhouse, with an increase in the number of seedlings produced, from $11.939,759$ to $17.581,974$ million respectively, of the 517 greenhouse, 500 are enclosed and are responsible for producing 99.80\% of inspected seedlings in June 2009.

The production system of citric seedlings in São Paulo is enforced by the Agency of Agriculture Defense of the State of São Paulo (ADAESP). According to its rules, for the production of citric seedlings, greenhouses are mandatorily rail with anti-aphid screen, with the minimum mesh determined as $0.64 \mathrm{~mm}$ per $0.20 \mathrm{~mm}$ (Carvalho, 2003). When working with a protected environment for seedling production, some kind of material is used to rail the sides (anti-aphid screen) and also cover the roof. Thus, it is known that the cover can be made with shading screens or screens of transparent materials. However, even with the addition of transparent materials, there is a reduction in the brightness of the interior of the greenhouse due to the accumulation of dust on its cover, thus reducing the passage of sunlight.

The effect of light intensity on seed germination, emergence, growth and survival of seedlings vary between species. In general, in seedling production, seeds are germinated in shady conditions, and the seedlings are transferred to conditions of greater brightness (Claussen, 1996). The germination rate, however, may be similar between shaded areas and full sun and vary between different degrees of shading (Morris et al., 2000) or greater germination and emergence homogeneously in different shading conditions then in full sun.

Assuming that the amount of radiation inside the protected environment is a factor that promotes different effects on the behavior of seedling emergence of citric varieties, the objective of this study was to investigate the influence of four different degrees of shading environments on the emergence and seedling growth in five varieties of citric rootstock.

\section{Material and methods}

The study was conducted from the $25^{\text {th }}$ October 2010 to the $8^{\text {th }}$ March 2011, on private property located in the municipality of Alegre-ES, located at $20^{\circ} 49^{\prime}$ south latitude and $41^{\circ} 32^{\prime}$ west longitude from Greenwich and $322 \mathrm{~m}$ altitude.

For the experiment, four tunnels lined with shade screens and covered with transparent plastic film were built. Each tunnel was constructed to be $2.60 \mathrm{~m}$ long, 1.20 $\mathrm{m}$ wide and $1.40 \mathrm{~m}$ high. Each tunnel was fixed on aluminum benches, with dimensions of $1 \mathrm{~m}$ high, $1.25 \mathrm{~m}$ wide and $2.90 \mathrm{~m}$ long, arranged in east west direction following its length. The experimental design was a completely randomized split plot, four environments in the plot and five varieties of rootstock subplots with four replications and twenty-five seeds per plot. Environments of $0 \%, 30 \%, 50 \%$ and $80 \%$ shading were applied, using shade screens of Sombrite ${ }^{\circledR}$ brand.

The rootstocks used were: Rangpur lime, Lemon Volkameriano, P. trifoliata, 'Swingle' citrumelo and Flying Dragon. The seeds of rootstocks were acquired in Citrolima Company, located in the state of São Paulo, Brazil. Sowing was performed in polyethylene tubes, tapered, with six streaks and a volume of $50 \mathrm{~cm}^{3}$, filled with Plantmax ${ }^{\circledR}$ Forest substrate. Irrigation was performed two times a day manually, by means of watering can with fine sieve. Fertilization was not performed during the conduct of the experiment.

With the aid of a Quantum Meter Radiometer mark Apogee Instruments Inc., Model SS-QMSW, the photosynthetic photon flux was measured 20 times during the trial, each reading was repeated four times at different locations within each tunnel. The mean values of the photosynthetic photon flux was 713, 405, 249 and 133 micromol m${ }^{-2} \mathrm{~s}^{-1}$ in environments with $0 \%, 30 \%, 50 \%$ and $80 \%$ shading, respectively. 60 days after sowing, emergence percentage (Brazil, 2009) and the emergence rate index, were evaluated, using the Maguire formula (1962): GSI = G1/N1 G2/N2 + + ... + Gn / Nn where: G1, G2, $\mathrm{Gn}=$ number of seedlings germinated in the first, second, until the last count and N1, N2, Nn = number of weeks from the first second until the last count; the number of leaves and the height expressed in centimeters. At 124 days, four replicates of ten plants were taken randomly, within each experimental plot, for evaluation of leaf area, with countertop appliance METER AREA LI-3100C, root dry mass and shoot, in grams, and total chlorophyll $(\mathrm{a}+\mathrm{b})$ content.

For determination of chlorophyll, three plants were collected randomly from each treatment, the first three leaves of these plants were collected and ground with the aid of scissors then this material was macerated. Of the resulting material from the maceration, $0.1 \mathrm{~g}$ samples were placed in a $25 \mathrm{ml}$ beckeres followed by the addition of 10 $\mathrm{ml}$ of $80 \%$ acetone and the beckeres were immediately sealed with plastic wrap to prevent evaporation of the acetone. Subsequently, beckeres were placed on a magnetic stirrer brand Marconi, model MA 085 and stirred for 10 minutes. The extracts were filtered using filter paper Melitta ${ }^{\circledR}$ brand and collected in $25 \mathrm{ml}$ volumetric flasks, completing the volume with distilled water to the final filtration. The optical density of the filtrates was read in a spectrophotometer (FEMTO ${ }^{\circledR}$, CIRRUS 80) at $\lambda 645$ and $663 \mathrm{~nm}$ using quartz cuvettes. From these readings, the concentration $\left(\mathrm{mg} \mathrm{cm}^{-3}\right)$ of total chlorophyll $(\mathrm{a}+\mathrm{b})$ was determined by reading the solutions and through the formula proposed by Arnon (1949).

$$
\text { Total chlorophyll }=20.2 * \mathrm{~A}_{645 \mathrm{~nm}}+8.02 * \mathrm{~A}_{663 \mathrm{~nm}}
$$

These values were transformed to total chlorophyll $\mathrm{a}+$ 
b) in leaves, expressed in ( $\left.\mu \mathrm{g} \mathrm{g}^{-1}\right)$, according to the suggestion of Richardson et al. (2002). Data were subjected to analysis of variance. For comparison of means the Tukey test at 5\% probability was employed.

\section{Results and discussion}

The analysis of variance shows that for the emergence rate index had no significant interaction between environmental factors and rootstock, observing significant effect only for the factor rootstock. Regarding the emergence percentage, number of leaves and root dry mass, both shading and rootstock factors observed significant effect, but not the interaction between them. As for the dry mass, leaf area, height and total chlorophyll (a + b), there is significant interaction between environmental factors and rootstock (Table 1).

Table 2 shows that, only within the treatment without shading, the means for the characteristic total chlorophyll content $(\mathrm{a}+\mathrm{b})$ do not differ between the different rootstocks. At $30 \%$ shading is observed that the Flying Dragon rootstock has the highest mean $\left(6,662.23 \mu \mathrm{g} \mathrm{g}^{-1}\right)$ and was statistically different only from Rangpur lime which presents mean of $2,818.76 \mu \mathrm{g} \mathrm{g}^{-1}$. At $50 \%$ shading, $P$. trifoliata shows the highest mean $\left(11,563.16 \mu \mathrm{g} \mathrm{g}^{-1}\right)$ and is statistically different from the other rootstocks. At $80 \%$ shading, the highest means, for total chlorophyll, of

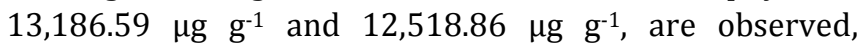
respectively, for $P$. trifoliata and Flying Dragon rootstock, they did not differ statistically among themselves.

For the rootstock Rangpur lime, the total chlorophyll content did not differ between the different levels of shading used, although there was a progressive increase in the value for this characteristic with increasing levels of shading. The $P$. trifoliata has the highest total chlorophyll in the two highest shading (50\% and $80 \%)$, which did not differ statistically among themselves. For other rootstocks, it is also possible to observe that there is a significant increase in total chlorophyll content with rising level of shading, observing the highest values when grown in an environment with $80 \%$ shading. We notice that increasing the level of shading promotes higher levels of total chlorophyll.

Table 1 - Summary of analysis of variance for emergence percentage (EP), emergence rate index (ERI), total chlorophyll (a + b) (TC) in $\mu \mathrm{g} \mathrm{g-1}$ fresh weight, leaf area (LA) in $\mathrm{cm}^{2}$, height (H) in $\mathrm{cm}$, number of leaves (NL), shoot dry mass (SDM) and root dry mass (RDM) both expressed in g of seedling rootstocks developed in different environments, Alegre-ES 2011.

\begin{tabular}{|c|c|c|c|c|c|c|c|c|c|}
\hline \multirow[b]{2}{*}{ SV } & \multicolumn{8}{|c|}{ Mean Square and Significance } & \multirow[b]{2}{*}{ RDM } \\
\hline & DF & EP & ERI & TC & LA & $\mathrm{H}$ & NL & SDM & \\
\hline SHADING & 3 & $618.8500^{* *}$ & $9.56^{\mathrm{ns}}$ & $149,715,600.0^{* *}$ & $12,937.81^{* *}$ & $6.45019^{* *}$ & $0.509562^{* *}$ & $0.113181^{* *}$ & $0.257219^{* *}$ \\
\hline ERROR (a) & 12 & 82.2500 & 3.67 & $1,327,441.0$ & 178.42 & 0.18273 & 0.045233 & 0.031966 & 0.025475 \\
\hline ROOTSTOCK & 4 & $2024.7500^{* *}$ & $74.26^{* *}$ & $80,735,810.0^{* *}$ & $8,731.39^{* *}$ & $37.93059^{* *}$ & $5.870463^{* *}$ & $0.496143^{* *}$ & $0.188239^{* *}$ \\
\hline ROOTSTOCK * SHADING & 12 & $136.3500^{\mathrm{ns}}$ & $3.47^{\mathrm{ns}}$ & $7,174,687.0^{* *}$ & $754.35^{* *}$ & $0.58299^{* *}$ & 0.168489 ns & $0.077116^{* *}$ & $0.058136^{n}$ \\
\hline ERROR (b) & 48 & 126.5833 & 3.83 & $2,352,516.0$ & 214.30 & 0.176136 & 0.094056 & 0.027048 & 0.040721 \\
\hline CV (\%) plot & & 11.50 & 20.59 & 19.07 & 13.02 & 7.76 & 5.09 & 16.58 & 15.12 \\
\hline CV (\%) subplot & & 14.26 & 21.02 & 25.38 & 14.27 & 7.64 & 7.34 & 15.25 & 19.12 \\
\hline
\end{tabular}

(1)**, * e ns, indicates significance at $1 \%, 5 \%$ and not significant; respectively by $\mathrm{F}$ test at $5 \%$ probability; (2)SV: source of variation; (3)DF: degree of freedom.

Table 2 - Mean values of total chlorophyll $(a+b)(T C)$ in $\mu g g^{-1}$ fresh weight of seedlings of citrus rootstocks grown in different environments, at 124 days after sowing, Alegre-ES 2011.

\begin{tabular}{lcccc}
\hline \multirow{2}{*}{ ROOTSTOCKS } & \multicolumn{4}{c}{ Environments } \\
\cline { 2 - 5 } & $0 \%$ & $30 \%$ & $50 \%$ & $80 \%$ \\
\hline Rangpur lime & $2.347 .61 \mathrm{Aa}$ & $2.818 .76 \mathrm{Ba}$ & $3.071 .28 \mathrm{Ca}$ & $4.861 .63 \mathrm{Ca}$ \\
Volkameriano & $2.395 .23 \mathrm{Ac}$ & $4.123 .13 \mathrm{ABbc}$ & $5.973 .44 \mathrm{BCb}$ & $8.847 .11 \mathrm{Ba}$ \\
P. trifoliata & $4.872 .24 \mathrm{Ab}$ & $5.845 .10 \mathrm{ABb}$ & $11.563 .16 \mathrm{Aa}$ & $13.186 .59 \mathrm{Aa}$ \\
Flying Dragon & $4.022 .23 \mathrm{Ac}$ & $6.662 .23 \mathrm{Abc}$ & $7.806 .51 \mathrm{Bb}$ & $12.518 .86 \mathrm{Aa}$ \\
'Swingle' citrumelo & $2.695 .74 \mathrm{Ab}$ & $3.869 .83 \mathrm{ABb}$ & $4.917 .65 \mathrm{BCb}$ & $8.448 .89 \mathrm{Ba}$ \\
\hline
\end{tabular}

Means followed by the same uppercase in columns and lowercase in rows, do not differ by Tukey test at $5 \%$ probability. 
This greater accumulation of chlorophyll at greater shading levels is possibly associated with the species adapting to the smaller amount of available radiation. Boardman (1977) found that leaves of plants grown under shade have higher chlorophyll concentration than those growing in full sun. One explanation for this behavior is that plants grown under low radiation have better development of grana; thus, the relative increase in chlorophyll $b$ is correlated with the intensity of radiation. Shaded leaves have higher chlorophyll content than the leaves in the sun (Kramer and Kozlowski, 1979), due to its high concentration of chlorophyll $b$ in shaded environments. This increase in chlorophyll b content is associated with slower degradation of chlorophyll b to chlorophyll a in relation to the increase in light intensity (Engel and Poggiani, 1991).

Scalon et al. (2002) suggest that increased chlorophyll b in leaves subjected to low brightness is an important feature because chlorophyll b collects the energy of other wavelengths and transferred to chlorophyll a, which effectively acts on photochemical reactions of photosynthesis and represents a mechanism of adaptation to the condition of lower light intensity. Therefore, leaves in the shade have generally higher chlorophyll concentration in relation to those grown in full sun (Castro and Alvarenga, 2002). Rego et al. (2006) conclude that the total chlorophyll is greater when seedlings of

Table 3 - Mean values of leaf area (LA) in $\mathrm{cm}^{2}$, of seedling rootstocks developed in different environments, at 124 days after sowing, Alegre-ES 2011.

\begin{tabular}{lcccc}
\hline \multirow{2}{*}{ ROOTSTOCKS } & \multicolumn{3}{c}{ Environments } \\
\cline { 2 - 5 } & $0 \%$ & $30 \%$ & $50 \%$ & $80 \%$ \\
\hline Rangpur lime & $71.24 \mathrm{Ab}$ & $77.01 \mathrm{Cb}$ & $109.59 \mathrm{BCa}$ & $106.43 \mathrm{Ba}$ \\
Volkameriano & $81.15 \mathrm{Ab}$ & $107.07 \mathrm{ABb}$ & $161.78 \mathrm{Aa}$ & $160.93 \mathrm{Aa}$ \\
$P$. Trifoliata & $63.75 \mathrm{Ac}$ & $71.29 \mathrm{Cbc}$ & $96.84 \mathrm{Cab}$ & $100.75 \mathrm{Ba}$ \\
Flying Dragon & $59.74 \mathrm{Ab}$ & $84.24 \mathrm{BCab}$ & $83.99 \mathrm{Cab}$ & $103.41 \mathrm{Ba}$ \\
'Swingle' citrumelo & $89.06 \mathrm{Ac}$ & $114.81 \mathrm{Abc}$ & $133.10 \mathrm{ABb}$ & $175.42 \mathrm{Aa}$ \\
\hline
\end{tabular}

Means followed by the same uppercase in columns and lowercase in rows, do not differ by Tukey test at $5 \%$ probability.

Table 4 - Mean values for height $(\mathrm{H})$ in $\mathrm{cm}$. the seedlings of citrus rootstocks grown in different environments, at 124 days after sowing, Alegre-ES 2011.

\begin{tabular}{lcccc}
\hline \multirow{2}{*}{ ROOTSTOCKS } & \multicolumn{3}{c}{ Environments } \\
\cline { 2 - 5 } & $0 \%$ & $30 \%$ & $50 \%$ & $80 \%$ \\
\hline Rangpur lime & $3.31 \mathrm{Cb}$ & $3.90 \mathrm{Cab}$ & $4.31 \mathrm{Ca}$ & $4.24 \mathrm{Ca}$ \\
Volkameriano & $2.82 \mathrm{Cc}$ & $3.80 \mathrm{Cb}$ & $4.37 \mathrm{Cab}$ & $4.98 \mathrm{Ca}$ \\
$P$. Trifoliata & $6.88 \mathrm{Ac}$ & $7.14 \mathrm{Abc}$ & $8.02 \mathrm{Aa}$ & $7.91 \mathrm{Aab}$ \\
Flying Dragon & $6.18 \mathrm{Ab}$ & $6.56 \mathrm{Aab}$ & $5.85 \mathrm{Bb}$ & $7.01 \mathrm{Ba}$ \\
'Swingle' citrumelo & $4.74 \mathrm{Bc}$ & $5.46 \mathrm{Bbc}$ & $5.85 \mathrm{Bab}$ & $6.56 \mathrm{Ba}$ \\
\hline
\end{tabular}

Means followed by the same uppercase in columns and lowercase in rows, do not differ by Tukey test at $5 \%$ probability.

Table 5 - Mean values of shoot dry mass (SDM) in g of seedling rootstocks developed in different environments, at 124 days after sowing, Alegre-ES 2011.

\begin{tabular}{llccc}
\hline \multicolumn{1}{c}{ ROOTSTOCKS } & \multicolumn{4}{c}{ Environments } \\
\cline { 2 - 5 } & $0 \%$ & $30 \%$ & $50 \%$ & $00 \%$ \\
\hline Rangpur lime & $0,7757 \mathrm{Ba}$ & $0,7407 \mathrm{Ca}$ & $0,9775 \mathrm{Ba}$ & $0,8245 \mathrm{Ba}$ \\
Volkameriano & $0,6960 \mathrm{Bc}$ & $0,8722 \mathrm{BCbc}$ & $1,2530 \mathrm{ABa}$ & $1,0330 \mathrm{ABab}$ \\
$P$. Trifoliata & $1,2918 \mathrm{Aa}$ & $1,1328 \mathrm{ABa}$ & $1,3610 \mathrm{Aa}$ & $1,0888 \mathrm{ABa}$ \\
Flying Dragon & $1,3295 \mathrm{Aa}$ & $1,2565 \mathrm{Aa}$ & $1,2342 \mathrm{ABa}$ & $1,1250 \mathrm{ABa}$ \\
'Swingle' citrumelo & $1,0213 \mathrm{ABa}$ & $1,1463 \mathrm{ABa}$ & $1,1028 \mathrm{ABa}$ & $1,3080 \mathrm{Aa}$ \\
\hline
\end{tabular}

Means followed by the same uppercase in columns and lowercase in rows, do not differ by Tukey test at $5 \%$ probability. 
Jequitibá-rosa (Cariniana legalis (Mart.) Kuntze) are grown under low light. This behavior is similar to that found by Marçal et al. (2014), who studied the emergence and early growth of seedlings of Cleopatra mandarin under different shade levels, and found that the chlorophyll content showed increasing response with increasing shading.

As for leaf area, presented in Table 3 , in the environment with zero shading, all rootstocks showed similar behavior but with significantly lower values than those with $80 \%$ shading environment. At this level of shading, rootstocks Volkameriano and 'Swingle' citrumelo
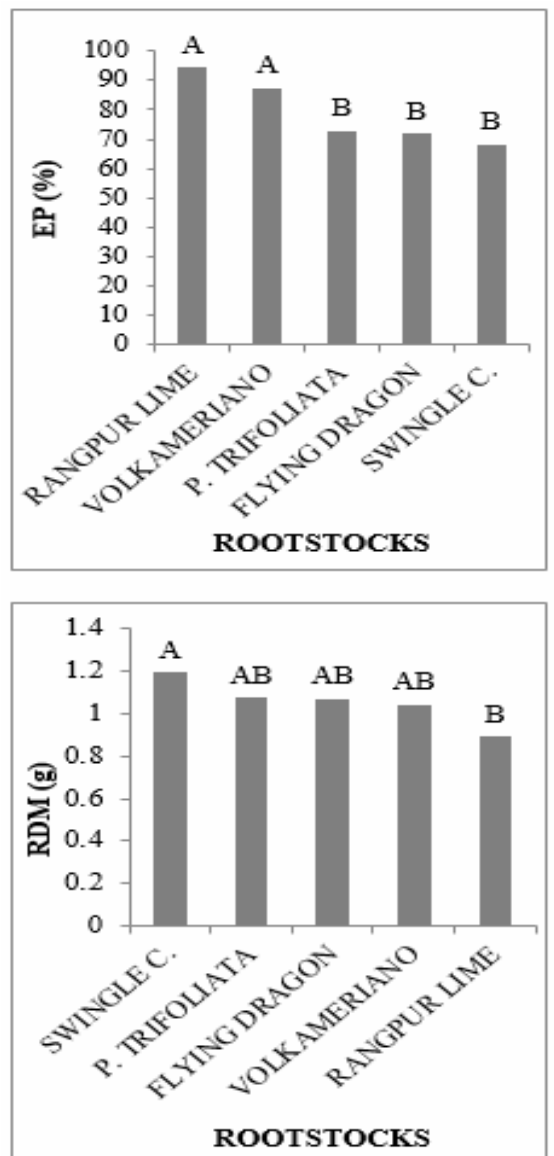

These results suggest that, under the conditions of this study, higher shading promotes more leaf numbers and larger leaf area, while environments with lower shading result in less leaf numbers and with smaller leaf area. Marçal et al. (2014) studied the effect of shading on the emergence and growth of seedlings of Cleopatra mandarin, and found that there was an increase in leaf area when there was increased shading with estimated point of maximum efficiency equal to $50.51 \mathrm{~cm}^{2}$ in response to shading 61.43\%. Dousseau et al. (2007) studied the behavior of Tapirira guianensis Alb. subjected to different
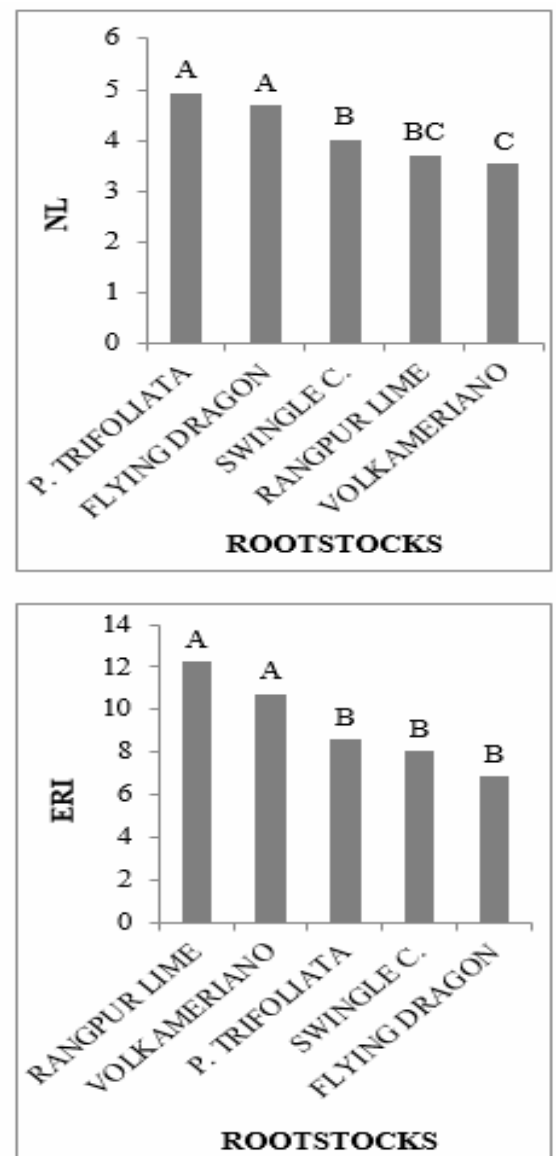

Fig. 1 - Comparison of the mean characteristics emergence percentage (EP), number of leaves (NL), root dry mass (RDM) and emergence rate index (ERI), depending on different rootstocks, at 124 days after sowing, Alegre - ES 2011. Letters followed by the same letter among rootstocks do not differ by Tukey, test at $5 \%$ probability.

presented the highest leaf area values and did not differ from each other. The rootstock Volkameriano does not differ from Flying Dragon, under 30\% shading. Also the rootstock 'Swingle' citrumelo did not differ from Rangpur lime in 50\% shading environment. The highest values for the characteristic leaf area were recorded in the larger shading levels ( $50 \%$ and $80 \%$ ), and only for the rootstock 'Swingle' citrumelo did the means differ at these levels of shading. In regards to the Flying Dragon rootstock, only the mean $\left(103.41 \mathrm{~cm}^{2}\right)$ in $80 \%$ shading environment differed significantly from the mean $\left(59.74 \mathrm{~cm}^{2}\right)$ at full sun. levels of shading, recording the highest values for leaf area in shading of $30 \%$ to $70 \%$. Taiz and Zeiger (2009) show that the shade grown leaves had higher leaf area and lower mesophyll thickness that leaves developed in the sun.

For seedling height in Table 4, the study of the interaction between environmental factors and rootstocks presents similar behavior to that of leaf area, where the highest values were recorded predominantly in environments with $50 \%$ and $80 \%$ shading. Yet for all tested environments, there is a statistical difference between the rootstocks, and the $P$. trifoliata stands out 
with the highest mean in shades $50 \%$ and $80 \%$, although it does not differ from Flying Dragon rootstock when grown in an environment with $0 \%$ and $30 \%$ shade. It is noted that there was an increase, in direct proportion, with the height of the plants and increased shading. The highest height mean between rootstocks was recorded in P. trifoliata with the exception that it did not differ from the Flying Dragon in environments with $0 \%$ and $30 \%$ shade.

The results of this study are consistent with the results obtained by Fonseca et al. (2002), who point out that the growing conditions in the greenhouse affect plant plants that have a greater number have greater availability of assimilates and thus higher growth (Faria et al. 2002). Morais et al. (2003) found marked reduction of net photosynthesis in shaded coffee, mainly due to anatomical changes and metabolic characteristics; reducing transpiration and leaf temperature due to the decrease of the incident radiation reducing water losses and the heating of the plant.

With regard to the production of citrus seedling quality, seedling height is one of the primary factors to be considered as a parameter that determines the time of
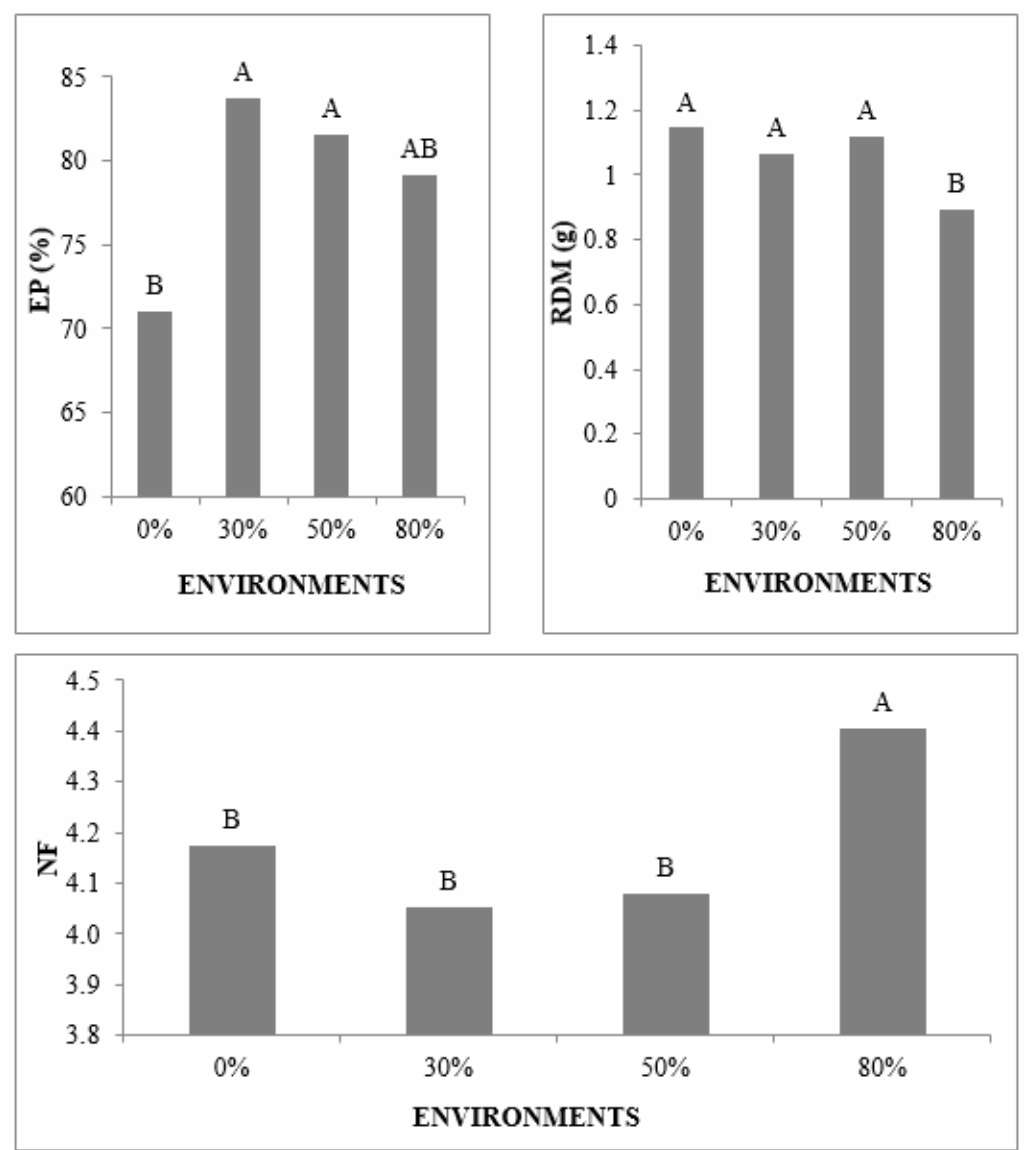

Fig. 2 - Values mean for emergence percentage (EP), root dry mass (RDM) and number of leaves (NL), for different environments, at 124 days after sowing, Alegre - ES 2011. Letters followed by the same letter among rootstocks do not differ by Tukey, test at $5 \%$ probability.

development. They further state that that there is a nursery effect on survival and early growth of seedlings in the field. This behavior is in agreement with Lemos et al. (2007) and Mazuchowski et al. (2007), who suggest that the increased rate of stem elongation occurs in proportion to the level of shading. Morais et al. (2003) found a greater height growth of the coffee (Coffea arabica L.) under shade of gandu (Cajanus cajan (L.) Millsp.), suggesting that it is trying to capture higher level of radiation, and compensate for low levels of photosynthetic and transpiration rates.

The photosynthetic process occurs mainly on leaves, so transplanting the tube into the bag. Thus, in this study it was observed that a shaded environment is a good option to reduce the residence time of the seedlings in tubes and provide better conditions for expression of seedling vigor.

The physiological seed vigor is affected by genetic makeup, environmental conditions during production, nutrition provided by the mother plant, stage of maturity and harvest, size and seed mass, seed age, mechanical integrity, attack by pathogens and insects, environmental conditions during storage and low temperature during imbibition (Sá, 1994; Carvalho and Nakagawa, 2000). In 
this context, it is observed that a $50 \%$ shaded environment provides better condition for expression of seedling vigor in tested rootstocks.

The results of the dry mass of shoots are shown in Table 5 , where it is observed that there is difference between rootstocks in all environments. However, only the rootstock Volkameriano responds significantly different when subjected to shading, with 50\% shading, it provided the highest mean value $(1.2530 \mathrm{~g})$, not presenting statistical difference from the $80 \%$ shading. A higher accumulation of dry biomass at $30 \%$ and $50 \%$ shading was observed for Dinizia excelsa (Varela and Santos, 1992), Licaria canella (Pinto et al., 1993) and Sclerolobium paniculatum (Felfili et al., 1999). Fonseca (2006) found that shading is necessary for seedlings of Pseudopiptadenia psilostachya, at least in the early stages of seedling development. In this case, one can consider that the seedling rootstocks under study are favored by the decrease in light intensity.

Fig. 1 notes the characteristics: emergence percentage and emergence rate index, the Rangpur lime rootstock does not differ from lemon Volkameriano, but these differ statistically from Trifoliate orange, 'Swingle' citrumelo and Flying Dragon, which do not differ when evaluated 60 days after sowing (DAS). These results are partly similar to those found by Schafer et al. (2005), who observed that the Rangpur lime rootstock has higher emergence rate index in relation to rootstock $P$. trifoliata orange and 'Swingle' citrumelo, however, these do not differ. In regards to the dry mass of the root, there is only a significant difference between the rootstock 'Swingle' citrumelo and Rangpur lime. In relation to the number of leaves, it can be observed the superiority of Flying Dragon and P. trifoliata rootstocks when compared to the other treatments. It is also to note that the 'Swingle' citrumelo does not differ from Rangpur lime, but it differs from Volkameriano.

Fig. 2 shows that the highest mean (83.7\%) for emergence percentage occurs in a $30 \%$ shading environment, which is statistically different from treatment without shade. Fonseca (2006) noted that shading increases the germination percentage of Pseudopiptadenia psilostachya. This pattern was also observed for three tropical tree species studied by McLaren and McDonald (2003). The lower germination of rootstock in full sun may be due to light intensity, the ambient temperature and humidity of the substrate. The increased temperature and increased water loss by evaporation from soil, in fully opened areas relative to the ground covered areas, can accelerate the deterioration of seeds (Morris et al., 2000), thereby reducing the germination percentage.

In Fig. 2, the highest mean (1.14 g) in dry root mass is obtained in the absence of shading, however, it differs only with the greatest shading treatment. It is assumed that these rootstock species have mechanisms and the capacity to adapt to environments with a certain degree of shading, maintaining the quality of the seedlings. The species that tolerate shade, are classified as tolerant, unlike the intolerant or heliophila that develop best in full light conditions (Connell and Slatyer 1977; Poggiani et al., 1992). $80 \%$ shading promotes low root dry mass yield. In this case, it would not be a viable option because a good root volume is essential for citric seedling production. A similar result was obtained by Almeida et al. (2005), in which the seedlings of Jacaranda puberula showed higher concentration of biomass in the dried root at 30\% and $50 \%$ shading, respectively. Tambelini and Perez (2007) found that the species Bauhinia holophylla (Bong.) Steud., Cassia chrysocarpa Desv. and Eriotheca gracilipes (K. Schum.) A. Robyns use the same type of strategy in the initial growth, with a large investment of dry mass of the root independent of shading used.

In regards to the characteristic number of leaves, the highest mean (4.40) is recorded for seedlings grown in an environment with $80 \%$ shading. In other treatments, there is no statistical difference between them. Similar results were observed by Carvalho et al. (2006), where the number of leaves differ between treatments of Licuri plants, with higher value for this feature when the plants have grown in more shadowed environments. According Nodari et al. (1999), the number of leaves is not the most suitable characteristics for representing differences in the growth of plants when exposed to different light levels, since there is a continuous fall and issue of new leaves. However, the growing environment has a direct influence on the phenomenon of falling leaves, with reflection in leaf area, site of photosynthesis, responsible for the growth of plants, when other production factors are optimized.

\section{Conclusions}

In general we note that the rootstocks evaluated in this study possess mechanisms (physiologic and morphological) to maintain the mean yield for dried aerial mass parts, even when subjected to high percentages of shading.

The rootstocks $P$. trifoliata and Flying Dragon, when subjected to higher percentages of shading $150 \%$ and $80 \%$ ) express a higher leaf area, higher total chlorophyll content, greater height and manage to maintain its dry shoot mass compared to other rootstocks.

The shading promotes an increase in dry mass of the aerial part of the rootstock Volkameriano. For other rootstocks there was no significant difference in the accumulation of dry mass of shoots when cultured with or without shading.

The shading of $30 \%$ and $50 \%$ favor the increase of 
emergence percentage and root dry mass of seedlings of all rootstocks at this stage of sowing.

\section{Acknowledgments}

The authors acknowledge to Coordenação de Aperfeiçoamento de Pessoal de Nível Superior - CAPES by master thesis scholarship.

\section{References}

Almeida, L. S., Maia, N., Ortega, A. R., \& Angelo, A. C. (2005). Crescimento de mudas de Jacaranda puberula Cham. em viveiro submetidas a diferentes níveis de sombreamento. Ciência Florestal, 15(3), 323-329.

Arnon D. I. (1949). Copper enzymes in isolated chloroplasts: polyphenoloxidases in Beta vulgaris. Plant Physiology, 24(1), 1-15. http://dx.doi.org/10.1104/pp.24.1.1 PMid:16654194 PMCid:PMC437905

Boardman, N. K. (1977). Comparative photosynthesis of sun and shade plants. Annual Review of Plant Physiology, 28, 355-377. http://dx.doi.org/10.1146/annurev.pp.28.060177.002035

Brasil. (2009). Ministério da Agricultura, Pecuária e Abastecimento. Regras para análise de sementes. Secretaria de Defesa Agropecuária - Brasília: Mapa/ACS, p.399.

Carvalho, N. M., \& Nakagawa, J. (2000). Ed. Sementes: ciência, tecnologia e produção. Jaboticabal: FUNEP, p.588.

Carvalho, N. O. S., Pelacani, C. R., Rodrigues, M. O. S., \& Crepaldi, I. C. (2006). Crescimento inicial de plantas de licuri (Syagrus coronata (Mart.) Becc.) em diferentes níveis de luminosidade. Revista Árvore, 30(3), 351-357. http://dx.doi.org/10.1590/S0100-67622006000300005

Carvalho, S. A. (2003). Regulamentação atual da agência de defesa agropecuária para produção, estocagem, comércio, transporte e plantio de mudas cítricas no estado de São Paulo. Laranja, 24(1), 199-239.

Castro, A. H. F., \& Alvarenga, A. A. (2002). Influência do fotoperíodo no crescimento inicial de plantas de confrei (Symphytum officinale L.). Ciência e Agrotecnologia, 26(1), 77-86.

Claussen, J. W. (1996). Acclimation abilities of three tropical rainforest to an increase in light intensity. Forest Ecology and Management, 80, 245-255 http://dx.doi.org/10.1016/0378-1127(95)03606-7

Connel, J. H., \& Slatyer, R. O. (1977). Mechanisms of succession in natural communities and their role in community stability and organization. American Naturalist, 111(982) 1119-1144. http://dx.doi.org/10.1086/283241

Dousseau, S., Alvarenga, A. A., Castro, E. M., Arantes, L. O. \& Nery, F. C. (2007). Superação de dormência em sementes de Zeyheria montana Mart. Ciência e Agrotecnologia, 31, 1744-1748. http://dx.doi.org/10.1590/S1413-70542007000600021

Engel, V. L., \& Poggiani, F. (1991). Estudo da concentração de clorofila nas folhas e seu espectro de absorção de luz em sombreamento em mudas de quatro espécies florestais nativas. Revista Brasileira de Fisiologia Vegetal, 3(1), 39-45.

Faria, W. S., Gaíva, N. H., \& Pereira, W. E. (2002). Comportamento de cinco genótipos de coqueiro (Cocos nucifera L.) na fase de germinação e de crescimento de mudas, sob diferentes sistemas de produção. Revista Brasileira de Fruticultura, 24(2), 458-462. http://dx.doi.org/10.1590/S0100-29452002000200035
Felfili, J. M., Hilgbert, L. F., Franco, A. C., Sousa-Silva, J. C., Resende, A. V., \& Nogueira, M. V. P. (1999). Comportamento de plântulas de Sclerolobium paniculatum Vog. var. rubiginosum (Tul.) Benth sob diferentes níveis de sombreamento, em viveiro. Revista Brasileira de Botânica, 22, 297-301.

Fonseca, E. P., Valéri, S. V., Miglioranza, E., Fonseca, N. A. N., \& Nogueira, M. V. P. (2002). Padrão de qualidade de mudas de Trema micrantha (L.) Blume, produzidas sob diferentes períodos de sombreamento. Revista Árvore, 26(4), 515-523. http://dx.doi.org/10.1590/S0100-67622002000400015

Fonseca, M. G., Leão, N. V. M., \& Santos, F. A. M. (2006). Germinação de sementes e crescimento inicial de mudas de Pseudo piptadenia psilostachya (Leguminosae) em diferentes ambientes de luz. Revista Árvore, 30(6), 885-891. http://dx.doi.org/10.1590/S0100-67622006000600003

Fundecitrus. (1996). Amarelinho, o papel do citricultor. Revista Fundecitrus, 7(78).

Fundecitrus. (2009). Viveiros. Araraquara - SP. Revista Fundecitrus, p.11.

Kramer, T., \& Koslowski, T. (1979). Physiology of Woody plants. New York, Academic Press, p.811.

Lemos, C. L., Matsumoto, S. N., Coelho, R. A., Lima, J. M., César, F. R. C. F., Bonfim, J. A., Guimarães, M. M. C., Santos, M. A. F., Araújo, G. S., \& Souza, A. J. de J. (2007). Avaliação do desenvolvimento vegetativo em cafeeiros sombreado e a pleno sol. Revista Brasileira de Agroecologia, 2(2), 1062-1065.

Maguire, J. D. (1962). Speeds of germination-aid selection and evaluation for seedling emergence and vigor. Crop Science, 2, 176-177. http://dx.doi.org/10.2135/cropsci1962.0011183X000200020033x

Marçal, T. de S., Martins, M. Q., Coelho, R. I., Amaral, J. A. T., \& Ferreira, A. (2014). Emergência e crescimento inicial de plântulas de tangerineira 'Cleópatra' submetidas a diferentes níveis de sombreamento. Nucleus, 11(1), 7-14.

Mazuchowski, J. Z., Silva, E. T., \& Maccari Junior, A. (2007). Efeito da luminosidade e da adição de nitrogênio no crescimento de plantas de Ilex paraguariensis St. Hil. Revista Árvore, 31(4), 619-627. http://dx.doi.org/10.1590/S0100-67622007000400006

McLaren, K. P., \& McDonald, M. A. (2003). The effects of moisture and shade on seed germination and seedling survival in a tropical dry forest in Jamaica. Forest Ecology and Management, 183, p.61-75. http://dx.doi.org/10.1016/S0378-1127(03)00100-2

Morais, H., Marur, C. J., Caramori, P. H., Ribeiro, A. M. de A., \& Gomes, J. C. (2003). Características fisiológicas e de crescimento de cafeeiro sombreado com guandu e cultivado a pleno sol. Pesquisa Agropecuária Brasileira, 38(10), 1131-1137. http://dx.doi.org/10.1590/S0100-204X2003001000001

Morris, M. H., Negreros Castillo, P., \& Mize, C. (2000). Sowing date, shade, and irrigation affect big-leaf mahogany (Swietenia macrophylla King). Forest Ecology and Management, 132, 173-181. http://dx.doi.org/10.1016/S0378-1127(99)00224-8

Nodari, R. O., Reis, M. S., Fantini, A. C., Mantovani, A., Ruschel, A., \& Welter, L. J. (1999). Crescimento de mudas de palmiteiro (Euterpe edulis Mart.) em diferentes condições de sombreamento e densidade. Revista Árvore, 23(3), 285-292.

Pinto, A. M., Varela, V. P., \& Batalha, L. F. P. (1993). Influência do sombreamento no desenvolvimento de mudas de louro 
pirarucu (Licariacanella (Meiss.) Kosterm.). Acta Amazônica, 23, 383-394.

Poggiani, F., Bruni, S., \& Barbosa, E. S. Q. (1992). Efeito do sombreamento sobre o crescimento das mudas de três espécies florestais. Revista do Instituto Florestal de São Paulo, 4(2), 564-569.

Pompeu Júnior, J., Figueiredo, J. O. de., Teófilo Sobrinho, J., Jorge, J. P. N., \& Jacon, J. R. (1986). Competição de clones de limão 'Cravo' e limão 'Volkameriano' como porta-enxerto para laranja 'Natal'. In: VIII Congresso Brasileiro de Fruticultura, Brasília. Anais... Brasília; Embrapa-DDT/CNPq, p.147-151.

Rego, G. M., \& Possamai, E. (2006). Efeito do sombreamento sobre o teor de clorofila e crescimento inicial do jequitibá-rosa. Boletim de Pesquisa Florestal. Embrapa Florestas, 53, 179-194.

Richardson A. D., Duigan S. P., \& Berlyn G. P. (2002). An evaluation of noninvasive methods to estimate foliar chlorophyll content. New Phytologist, 153, 185-194. http://dx.doi.org/10.1046/j.0028-646X.2001.00289.x

Sá, M. E. (1994). Importância da adubação na qualidade de sementes. In: Sá, M. E., \& Buzetti, S. Importância da adubação na qualidade dos produtos agrícolas. São Paulo: Ícone, p.65-98.

Scalon, S. P. Q., Mussury, R. M., Rigoni, M. R., \& Veraldo, F. (2002). Crescimento inicial de mudas de espécies florestais nativas sob diferentes níveis de sombreamento. Revista Árvore, 26(1), 1-5.

Schafer, G., Souza, P. V. D. de., Daudt, R. H. S., \& Dornelles, A. L. C. (2005). Substratos na emergência de plântulas e expressão da poliembrionia em porta-enxertos de citros. Ciência Rural, 35(2), 471-474. http://dx.doi.org/10.1590/S0103-84782005000200039

Silva, M. M., Pompeu Júnior, J., Beretta, M. J. G., Rosseti, V., \& Negri, J. D. (1990). Diversificação de porta-enxertos em decorrência do declínio dos Citros no estado de São Paulo. Revista Laranja, 11(1), 309-321.

Siqueira, D. L. de., Vasconcellos, J. F. F. de., Dias, D. C. F. S., \& Pereira, W. E. (2002). Germinação de sementes de porta-enxertos de citros após o armazenamento em ambiente refrigerado. Revista Brasileira de Fruticultura, 24(2), 317-322. http://dx.doi.org/10.1590/S0100-29452002000200009

Taiz, L., \& Zeiger, E. (2009). Fisiologia Vegetal. 4. ed. Porto Alegre: Artmed, p.819.

Tambelini, M., \& Perez, S. C. J. G. A. (2007). Produção de mudas de três espécies de cerrado sob diferentes intensidades luminosas. Revista Brasileira de Biociências, 5(2), 879-881.

Varela, V. P., \& Santos, J. (1992). Influência do sombreamento na produção de mudas de Angelim pedra (Dinizia excelsa Ducke). Acta Amazonica, 22(3), 407-411. 